\title{
The effect of classical Turkish and Western music on university students' exam stress level, blood pressure and pulse rate: a randomized controlled trial
}

\author{
Klasik Türk ve Batı müziğinin üniversite öğrencilerinin sınav stres düzeyi, \\ kan basıncı ve nabız değerlerine etkisi: randomize kontrollü bir çalışma
}

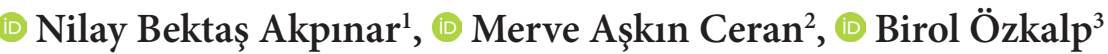 \\ ${ }^{1}$ Medipol University, Vocational School of Health Services, First And Emergency Aid Program, Ankara, Turkey \\ ${ }^{2}$ KTO Karatay University School of Health Sciences, Nursing Department, Konya, Turkey \\ ${ }^{3}$ KTO Karatay University, Faculty of Medicine, Department of Medical Microbiology, Konya, Turkey
}

Cite this article as / Bu makaleye atıf için: Bektaş Akpınar N, Ceran MA, Özkalp B. The effect of classical Turkish and Western music on university students' exam stress level, blood pressure and pulse rate: a randomized controlled trial. J Health Sci Med 2020; 3(3): 216-220.

\begin{abstract}
Introduction: Exam stress may cause anxiety, worry, emotion and condition changes in university students. Students use various methods to cope with exam stress. Music is a method used to cope with anxiety that reduces the stress level of individuals by creating a deep relaxation and providing a therapeutic environment. This research was carried out in a randomized controlled pre-test and post-test to examine the effect of regular Classical Turkish and Western music on university students' exam stress level, blood pressure and pulse findings.

Material and Method: The sample of the study consisted of 88 students ( 40 experiments, 48 controls) studying in different departments at this University between November 2017 and February 2018. Data were collected by exam anxiety scale and personal information form. The experiment group was played 25 minutes 4 days a week total 6 weeks and Classic Western and Classical Turkish music just before the exam. Examination anxiety scale was re-applied to the experimental and control groups just before the examination, and the vital sign findings of the students were examined.

Findings: The mean score of the experimental group was $41.40 \pm 9.40$ and the postest mean score was $23.20 \pm 4.16$ and there was a statistically significant difference $(\mathrm{p}<0.01)$. In addition, diastolic, systolic blood pressure and pulse rate of the students in the group who listen to music were lower than those who did not listen to music.

Conclusion: It has been determined that regular music performance is an effective method in reducing the stress levels and anxiety levels of the students.
\end{abstract}

Keywords: Blood pressure, exam stress, music listening, nursing, pulse rate

ÖZ

Giriş: Sınav stresi üniversite öğrencilerinde kaygı, endişe, duygu durum değişikliklerine neden olabilmektedir. Öğrenciler sınav stresi ile baş edebilmek için çeşitli yöntemler kullanmaktadır. Müzik ise bireylerde derin düzeyde relaksasyon oluşturup, terapötik ortam sağlayarak bireylerin stres düzeylerini azaltan kaygı ile baş etmede kullanılan bir yöntemdir. Bu araştırma düzenli Klasik Türk ve Batı müziği dinletilmesinin üniversite öğrencilerinin sınav stres düzeyi, kan basıncı ve nabız bulgularına etkisini incelemek amacıyla ön test-son test randomize kontrollü olarak yapılmıştır.

Gereç ve Yöntem: Araştırmanın örneklemini Aralık 2017-Şubat 2018 tarihleri arasında Üniversitede farklı bölümlerde okuyan toplamda 88 öğrenci (40 deney, 48 kontrol) oluşturmuştur. Veriler 'sınav kaygı ölçeği' ve 'kişisel bilgi formu' ile toplanmıştır. Deney grubuna 6 hafta boyunca haftada 4 gün -25 dakika ve sınavdan hemen önce Klasik Batı ve Klasik Türk Müziği dinletilmiştir. Deney ve kontrol grubuna sınavdan hemen önce sınav kaygı ölçeği tekrar uygulanmış, öğrencilerin kan basıncı ve nabız bulgularına bakılmıştır.

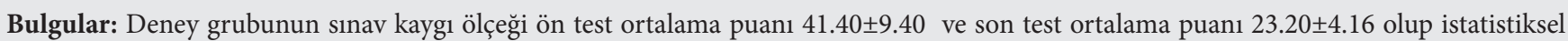
olarak anlamlı farklılık tespit edilmiştir $(\mathrm{p}<0,01)$. Ayrıca müzik dinleyen grupta yer alan öğrencilerin diastolik, sistolik kan basıncı ve nabız değerleri müzik dinlemeyen gruba göre daha düşük tespit edilmiştir.

Sonuç: Düzenli müzik dinletisinin öğrencilerin sınav stres düzeylerini ve anksiyetelerini azaltmada etkili bir yöntem olduğu tespit edilmiştir.

Anahtar Kelimeler: Kan basıncı, sınav stresi, müzik dinletisi, hemşirelik 


\section{INTRODUCTION}

Music has been used in various health care applications from past to present. Music therapy uses music and music activities to meet the physical, psychological, social and mental needs of individuals $(1,2)$.

According to the National Association for Music and Therapy (NAMT), music is used for the correction, care and improvement of mental and physical health. (3).

Treatment with music has been used as a treatment option in many areas of medicine in recent years. Music therapists in the USA and Europe are trained, music treatment is used in special subjects such as Alzheimer's disease, personality disorders, reducing the symptoms related to chemotherapy in oncology patients and improving the quality of life of people with disabilities. The Traditional and Complementary Medicine in the Ministry of Health in Turkey has replaced Music Therapy Applications applications (4). Music(musical) therapy is a non-invasive relaxation technique that is also included in nursing practice and is considered and applied as a therapy method $(3,4)$.

Music is capable of creating deep relaxation. It has physiological and psychological effects in individuals. Physiological effects, psychophysiological stress, pain, anxiety, and reduce the isolation creates a behavior change. The music reduces the effect of the body's neuroendocrine response to stress, and by activating the parasympathetic nervous system, it can help to restore physiological life signs and cardiac arrhythmias, such as blood pressure, pulse and respiration, by decreasing the secretions of catecholamine. The psychological effects of music (musical) therapy are to increase the spiritual conditions of a person, to eliminate fear and anxiety and thus to reduce anxiety (5-7).

Marshall and Tomcala (8) (1981) examined the effects of different music genres on stress and found that the levels of stress of the subjects were different, and that all music types had the same psychotherapeutic effect. This another study found that the rate of heart rate, blood pressure and respiratory rate of the patients listening to music were significantly lower than the other group of patients who were not listening to music (9).

Listening to music can increase the emotions, motivations and self-expression of young people. (10-12). In a study, it was determined that anxiety, depression and stress levels of the students were decreased and self-efficacy perceptions increased after music (musical) treatment applied to university students (12). In our study determined that students' concentration and positive emotions increased and pain, sadness feelings decreased by using jazz for therapy to reduce the problems experienced by students who were new to university (13).
The aim of this study was to investigate the effects of classical Turkish and Western music on the level of examination stress and basic life findings of university students.

\section{MATERIAL AND METHOD}

This study was conducted as a randomized controlled pre-test. This study was approved by the university /local human research ethics committee and all procedures performed in studies involving human participants were in accordance with the ethical standards of the institutional and/or national research committee and with the 1964 Helsinki Declaration and its later amendments or comparable ethical standards. The study was carried out with the permission of KTO Karatay University Medical Faculty Non-pharmaceutical and Medical Device Research Ethics Committee (Permission granted: 26.12.2017, Decision no: 8/003). The aim of the study and method was explained to the students who meet the criteria for inclusion in the study, their consent was taken to participate in the research by emphasizing that participation in the research was based on volunteering.

The sample of the study was assigned to random control and experimental groups of students who studied at different departments of KTO Karatay University (in order to prevent interaction between students) ( $\mathrm{n}=40$ experiments, 48 controls). The experimental group was initially 44 people, and 4 students were excluded from the study due to their inability to attend the music hours regularly.

The test and control groups were firstly administered the exam anxiety scale and personal information form. Music genre, listening period literature and music department were determined by interviewing with faculty members. As a result of the related literature, it has been determined that listening to music continuously is not effective in individuals but that the instrumental music played for 3-4 days a week and 15-30 minutes at a time is the most frequently applied music (14-17).

Blood pressure and pulse values of the experimental group were examined before the visa exams Classic Western and Classical Turkish music was played for 25 minutes in the experimental group, 4 days a week after the midterm exams in the room arranged with the appropriate sound system just before the exam. In order not to be disturbed by the students during the music hours, a note was hung over the door of the room and the hours were reserved by the university administration for the music performance.

Before the examination, the test anxiety scale was readministered to the experimental and control groups, and the basic life findings (blood pressure and pulse) of the students were examined. 


\section{Data Collection}

Data were collected via the "Personal Information Form", "Examination Anxiety Scale (EAS). Face to face interviews were used in a private room in the school and each session lasted for 20 minutes

\section{Personal İnformation Form}

The related literature is searched and questions such as age, gender, the department they study, their relationship with the teachers and the success of the exams are included (9-13).

\section{Examination Anxiety Scale (EAS)}

The Examination Anxiety Scale (SDQ) was prepared by Spielberg and a group of doctoral students at the University of South Florida between 1974-1979. The validity and reliability study of the scale in our country was determined by Öner (16) and the reliability coefficient was 0.89 . The scale, which consists of 20 items, consists of Delusion (8 items) and Affectiveity (12 items) subtests representing two different dimensions. The scale is a Likert-type scale with a score of 1-4 and the lowest score is 20 and the highest score is 80 (18).

\section{Evaluation of Data}

The data obtained in this study were analyzed with SPSS 17 package program. Whether the data showed normal distribution was determined using Kolmogorov-Smirnov and Shapiro-Wilk tests. Non-normally distributed variables were evaluated by Mann-Whitney $U$ and Wilcoxon test. In summarizing categorical variables, the number and percentage values are given. Mean, standard deviation and median (min-max) values were used to summarize the examination stress scale data. Pearson correlation test was performed to determine whether there was a significant difference in the anxiety levels before and after the music (pre and post test) therapy. Statistical significance level was set to $\mathrm{p}<0.05$.

\section{RESULT}

The mean age of the individuals in the experimental group was $19.08,52.3 \%$ were women, $\%$ of was nursing, $34.9 \%$ of were studied in the logistics department and $60 \%$ of them described the school success as good (Table 1).

The mean age of the individuals in the control group was $20.02,52.1 \%$ were women, $15 \%$ were nurses and $17.5 \%$ were in energy management, $62.5 \%$ had good school success (Table 1). In terms of socio-demographic variables, education and control groups have similar characteristics $(\mathrm{p}>0.05)$.
Table 1. Socio-demographic characteristics of the students in experimental and control groups $(\mathrm{n}=88)$

\begin{tabular}{|c|c|c|c|c|c|c|}
\hline \multirow[t]{2}{*}{$\begin{array}{l}\text { Socio- } \\
\text { demografhic } \\
\text { characteristics }\end{array}$} & \multicolumn{2}{|c|}{$\begin{array}{l}\text { Control } \\
\text { group (48) } \\
\text { Number } \\
\text { percentage }\end{array}$} & \multicolumn{2}{|c|}{$\begin{array}{c}\text { Experimental } \\
\text { group }(40) \\
\text { Number } \\
\text { percentage }\end{array}$} & \multicolumn{2}{|c|}{$\begin{array}{c}\text { Total (88) } \\
\text { Number } \\
\text { percentage }\end{array}$} \\
\hline & $\mathbf{N}$ & $\%$ & $\mathbf{N}$ & $\%$ & $\mathbf{N}$ & $\%$ \\
\hline \multicolumn{7}{|l|}{ Age } \\
\hline $18-21$ & 44 & 91.6 & 38 & 95 & 82 & 93.1 \\
\hline $22-25$ & 4 & 80.3 & 2 & 5 & 6 & 6.9 \\
\hline \multicolumn{7}{|l|}{ Gender } \\
\hline Female & 25 & 52.1 & 21 & 51 & 46 & 52.3 \\
\hline Male & 23 & 47.9 & 19 & 49 & 42 & 47.8 \\
\hline \multicolumn{7}{|l|}{ Program } \\
\hline Nursing & 12 & 34.9 & 6 & 15 & 18 & 20.5 \\
\hline $\begin{array}{l}\text { Child } \\
\text { devolepment }\end{array}$ & 12 & 34.9 & 6 & 15 & 18 & 20.5 \\
\hline Dialysis & 12 & 34.9 & 7 & 17.5 & 19 & 21.6 \\
\hline $\begin{array}{l}\text { Energy } \\
\text { management }\end{array}$ & 12 & 34.9 & 7 & 17.5 & 19 & 21.6 \\
\hline $\begin{array}{l}\text { International } \\
\text { trade and } \\
\text { logistics }\end{array}$ & 12 & 34.9 & 7 & 17.5 & 19 & 21.6 \\
\hline $\begin{array}{l}\text { Islamic } \\
\text { economics and } \\
\text { finans }\end{array}$ & 12 & 34.9 & 7 & 17.5 & 19 & 21.6 \\
\hline \multicolumn{7}{|l|}{ Success status } \\
\hline Successful & 30 & 62.5 & 24 & 60 & 54 & 61.4 \\
\hline Intermadiate & 14 & 29.2 & 12 & 30 & 26 & 29.5 \\
\hline Unseccessful & 4 & 8.3 & 4 & 10 & 8 & 9.1 \\
\hline
\end{tabular}

In our study, pulse and blood pressure values of the experimental group were examined before the visa test. Pulse rate of the experimental group was measured as $82.38 \pm 10.50$, systolic blood pressure was measured as $130.55 \pm 17.00$ and diastolic blood pressure was measured as $75.16 \pm 13.80$. These values were re-examined before the final exams of the experimental group; the pulse was found to be $78.50 \pm 8.11$, systolic blood pressure was $115.20 \pm 19.3$, diastolic blood pressure was $72.58 \pm 12.19$, and a statistically significant difference was found in the values $(\mathrm{p}<001)$ (Table 2$)$.

\begin{tabular}{|c|c|c|c|c|}
\hline & & $\begin{array}{c}\text { Before } \\
\text { mean } \pm \text { SD }\end{array}$ & $\begin{array}{c}\text { After } \\
\text { mean } \pm \text { SD }\end{array}$ & $\mathbf{p}$ \\
\hline \multirow{3}{*}{$\begin{array}{l}\text { Experimental } \\
\text { group }(n=40)\end{array}$} & Pulse & $82.38 \pm 10.50$ & $78.50 \pm 8.11$ & $\mathrm{p}=0.004$ \\
\hline & $\begin{array}{l}\text { Systolic } \\
\text { pressure }\end{array}$ & $130.55 \pm 17.00$ & $115.20 \pm 19.3$ & $\mathrm{p}<.001$ \\
\hline & $\begin{array}{l}\text { Diastolic } \\
\text { pressure }\end{array}$ & $75.16 \pm 13.80$ & $72.58 \pm 12.19$ & $\mathrm{p}<.001$ \\
\hline \multirow{3}{*}{$\begin{array}{l}\text { Control group } \\
(\mathrm{n}=48)\end{array}$} & Pulse & $85.60 \pm 14.85$ & $85.70 \pm 15.54$ & $\mathrm{p}=0.90$ \\
\hline & $\begin{array}{l}\text { Systolic } \\
\text { pressure }\end{array}$ & $140.02 \pm 13.77$ & $140.25 \pm 15.95$ & $\mathrm{p}=0.285$ \\
\hline & $\begin{array}{l}\text { Diastolic } \\
\text { pressure }\end{array}$ & $73.72 \pm 7.64$ & $72.99 \pm 9.87$ & $\mathrm{p}=0.226$ \\
\hline
\end{tabular}


In our study, the control group's pulse rate was measured as $85.60 \pm 14.85$, systolic blood pressure was $140.02 \pm 13.77$, and diastolic blood pressure was $73.72 \pm 7.64$. These values were re-examined before the final exams of the control group; pulse rate was found to be $85.70 \pm 15.54$, systolic blood pressure was $140.25 \pm 15.95$, and diasolic blood pressure was $72.99 \pm 9.87$, and no statistically significant difference was found ( $>>0.05)$ (Table 2).

Pre-test mean score of the exam anxiety scale of the experimental group was $41.40 \pm 9.40$ and the last test mean score was $23.20 \pm 4.16$ and a statistically significant difference was found $(\mathrm{p}<0.01)$. There was a statistically significant positive correlation between the exam anxiety scale pre-test and post-test scores of the experimental group $(\mathrm{r}=0.938, \mathrm{p}<0.05)$ (Table 3$)$.

\begin{tabular}{|l|ccc|}
\hline $\begin{array}{l}\text { Table 3. Exam anxiety scale of the experimental and control group } \\
\text { student }\end{array}$ & $\begin{array}{c}\text { Pre-exam } \\
\text { anxiety scale } \\
\text { mean } \pm \text { SD }\end{array}$ & $\begin{array}{c}\text { Post-exam } \\
\text { anxiety scale } \\
\text { mean } \pm \text { SD }\end{array}$ & p \\
\hline $\begin{array}{l}\text { Experimental group } \\
(\mathrm{n}=40)\end{array}$ & $41.40 \pm 9.40$ & $23.20 \pm 4.16$ & $\mathrm{p}<.001$ \\
$\begin{array}{l}\text { Control group } \\
(\mathrm{n}=48)\end{array}$ & $56.10 \pm 13.25$ & $55.23 \pm 12.94$ & $\mathrm{p}=0.165$ \\
\hline
\end{tabular}

The pre-test mean score of the exam anxiety scale of the control group was $56.10 \pm 13.25$ and the posttest mean score was $55.23 \pm 12.94$. There was no statistically significant difference between the scores ( $\mathrm{p}>0.05)$ (Table 3$)$.

\section{DISCUSSION}

In our study, it was determined that there was a significant decrease in exam anxiety scores of students listening to music $(\mathrm{p}<0.005)$. Studies have shown that listening to music in parallel with our research findings is effective in reducing stress and anxietylevels of individuals $(5,10,11,19$ 21). It has been determined that music (musical) therapy applied to students studying dentistry reduces students' stress levels (11). In another study, it was found that $10 \%$ of the students preferred to listen to music in order to reduce the stress of exams. 21. It was determined that the music played to the students for one hour and five days, decreases the depression and anxiety scores of the students (22).

In our country, test anxiety in university students is a situation starting from university entrance exams and continuing to be experienced during university education. During university education, students are experiencing tension due to being successful in the foreseeable exams especially in the future and this tension may turn into anxiety. Exam anxiety can be perceived as a threatening and frightening situation in students. Students with more anxiety experience more anxiety and their reactions in the form of affective reactions may be more intense $(1,10,11)$.
Exam anxiety can cause symptoms such as attention deficit, thinking disability, palpitations, fatigue in individuals. Listening to music as a method of coping with exam stress may help to develop a healthy self, positive mood, and depressive symptoms. Music reduces anxiety and stress in individuals, helps individuals to relax and there is no side effect in the application $(16-19,21,22)$ Immediately after being exposed to a short cognitive stress, it was stated that relaxing self-selected relaxing or listening to classical music reduces negative emotional states and physiological arousal (23).

It is also known that listening to regular music helps stimulate cognitive capacity, increase visual intelligence, increase concentration and facilitate learning $(5,12,24,25)$. It was determined that nursing students listening to music once a week remember the appropriate rhythms for $\mathrm{CPR}$ (24).

In our study, there was a significant decrease in blood pressure and pulse values of students listening to music during and before the examination. Blood pressure and pulse values of the group who did not listen to music were higher. Regular music increases endorphin secretion, reduces anxiety, regulates heart rhythm, lowers blood pressure, relaxes muscles $(5,14,16,17,19)$.

Gagner Tjellesen et al. (26) by determining that listening to music can stimulate alpha waves in the brain that cause relaxation, they found that music reduced pain, causing blood pressure and heart rate drop. It was found that the values of diastolic blood pressure of the group who listen to music in the first blood collection were lower (24). It was determined that patients who had pain due to cancer lost their pain due to music played for 30 minutes and it was determined that there was no need for analgesics (14). This another study found that patients in the experimental group had a decrease in diastolic and systolic blood pressures compared to the control group, but there was no difference between the experimental and control groups in terms of pulse, respiration and cortisol levels in the experimental group (16).

\section{CONCLUSION}

Regular Classical Turkish and Western music can be used to reduce stress in students. The above study results show that musical stimuli have the ability to produce positive effects when used correctly on humans. In addition, by decreasing the anxiety levels of the students, it decreased the systolic-diastolic tension and pulse rate and positively influenced the physiological response of the body to stress. In view of the results of this research, we recommend that students be applied to reduce their stress and anxiety and to increase their motivation. 


\section{Limitations of the Study}

This research is limited to students studying in six departments only at this University and can only generalize the results to these students. For further studies, it can be carried out at many universities in different cities at the same time. In addition, the choice of music was not left to the students and the music was decided upon by the faculty members who had a certificate of therapy. Even if the students chose the music types of their choice, the result could be different.

\section{ETHICAL DECLARATIONS}

Ethics Committee Approval: The study was carried out with the permission of KTO Karatay University Medical Faculty Non-pharmaceutical and Medical Device Research Ethics Committee (Permission granted: 26.12.2017, Decision no: 8/003).

Informed Consent: Informed consent was obtained from all participants who participated in this study.

Referee Evaluation Process: Externally peer-reviewed.

Conflict of Interest Statement: The authors have no conflicts of interest to declare.

Financial Disclosure: The authors declared that this study has received no financial support.

Author Contributions: All of the authors declare that they have all participated in the design, execution, and analysis of the paper, and that they have approved the final version.

\section{REFERENCES}

1. Murrock CJ, Higgins PA. The theory of music, mood and movement to improve health out comes. J Adv Nurs 2009; 65: 2249-57.

2. McKinney CH, Tims FC, Kumar AM, Kumar M. The effect of selected classical music and spontaneous imagery on plasma betaendorphin. J Behav Med 1997; 20: 85-99.

3. American Music Therapy Association. What is music therapy https://www.musictherapy.org/research/guidance_for_music_ listening_programs/ Accessed May 19, 2018.

4. T.C SAĞLIK Bakanlığı. Geleneksel ve Tamamlayıcı Tip Uygulamaları Yönetmeliği. http://getatportal.saglik.gov. tr/TR,8461/geleneksel-ve-tamamlayici-tip-uygulamalariyonetmeligi.html. Accessed may 23, 2018.

5. Landis-Shack N, Heinz AJ, Bonn-Miller MO. Music therapy for posttraumatic stress in adults: a theoretical review. Psychomusicology 2017; 27: 334-42.

6. Chanda ML, Levitin DJ. The neurochemistry of music. Trends Cogn Sci 2013; 17: 179- 93.

7. McKinney CH, Tims FC, Kumar AM, Kumar M. The effect of selected classical music and spontaneous imagery on plasma betaendorphin. J Behav Med 1997; 20: 85- 99.

8. Marshall OW, Tomcala, M. Effects of different genres of music on stress levels. East Texas State University, 1981.
9. Miluk-Kolasa B, Matejek M, Stupnicki R. The effects of music listening on changes in selected physiological parameters in adult presurgical patients. J Music Ther 1996; 33: 208-18.

10. Ghasemi M, Lotfollahzadeh H, Kermani-Ranjbar T, Kharazifard MJ. Effect of music practice on anxiety and depression of iranian dental students. J Dent (Tehran) 2017; 14: 138-43.

11. Wu SM. Effects of music therapy on anxiety, depression and selfesteem of undergraduates. Psychologia 2002; 45: 104-14.

12. Azizinezhad M, Hashemi M, Darvishi S. Music as an educationrelated service to promote learning and skills acquisition. Procedia - Social Behavioral Sci 2013; 93: 142-5.

13. Barber NL, Barber JL. Jazz For Success: Alternative music therapy to enhance student development in college. J College Univ Student Housing 2005; 33: 4-9.

14. HuangS T, Good M, Zauszniewski JA. The effectiveness of music in relieving pain in cancer patients: a randomized controlled trial. Int J Nurs Stud 2010; 47: 1354-62.

15. Kaya A. The effects of religion-based music therapy on emotional state, anxiety, perceived stress levels of university students. Int J Religion \& Philosophical Res 2018; 1: 58-62.

16.Özdemir Ü, Tasçı S, Yıldızhan E, Aslan S, Eser B. The effect of classical turkish music on pain severity and anxiety levels in patients undergoing bone marrow aspiration and biopsy. Pain Manag Nurs 2019; 20: 82-7.

17. Stanczyk MM. Music therapy in supportive cancer care. Rep Pract Oncol Radiother 2011; 8: 170-2.

18. Öner N. Sınav Kaygısı Envanteri El Kitabı, Yüksek Öğrenimde Rehberliği Tanıtma ve Rehber Yetiștirme Vakfı, 1990 Yayın No:1, İstanbul.

19.Liu YH, Lee CS, Yu CH, Chen CH. Effects of music listening on stress, anxiety, and sleep quality for sleep-disturbed pregnant women. Women Health 2016; 56: 296-311.

20. Yokus T. The relationship between the state-trait anxiety levels and the academic achievement of music teacher candidates. Int Online J Primary Educ 2013; 2: 25-31.

21. Afzal H, Afzal S, Siddique SA, Naqvi SA. Measures used by medical students to reduce test anxiety. J Pak Med Assoc 2012; 62: 982-6.

22. Çam $\mathrm{O}$, Altınköprü $\mathrm{H}$. The effect of music upon the emotional status and styles to cope with stress of university students. Motif Akademi Halkbilimi Derg 2013; 11: 262-72.

23.Labbé E, Schmidt N, Babin J, Pharr M. Coping with stress: the effectiveness of different types of music. Appl Psychophysiol Biofeedback 2007; 32: 163-8.

24. Tastan S, Ayhan H, Unver V, et al. The effects of music on the cardiac resuscitation education of nursing students. Int Emerg Nurs 2017; 31: 30-5.

25. Ince S, Çevik K. The effect of music listening on the anxiety of nursing students during their first blood draw experience. Nurse Educ Today 2017; 52: 10-4.

26. Gagner-Tjellesen D, Yurkovich EE, Gragert M. Use of music therapy and other ITNIs in acute care. J Psychosoc Nurs Ment Health Serv 2001; 39: 26-37. 